\title{
The importance of iron chelation and iron availability during PpIX-induced photodynamic therapy
}

Die Bedeutung von Eisenchelation und Eisenverfügbarkeit während der PpIXinduzierten photodynamischen Therapie

\begin{abstract}
Background: Protoporphyrin IX (PpIX)-induced photodynamic therapy (PDT) is being utilised as a topical method of localised ablation of certain non-melanoma skin cancers and precancers. Standardised protocols have been implemented to good effect when the disease remains superficial but improvement is required to treat thicker or acrally located conditions. Concurrent administration of an iron chelator during PpIX-PDT has been demonstrated to increase cellular accumulation of PpIX by reducing its bioconversion to haem (an iron dependent process) thus increasing cell kill on subsequent irradiation. Iron however, can also play a role in reactive oxygen species (ROS) generation and limiting its availability via chemical chelation which could theoretically reduce the efficacy of PpIX-PDT, so that a response less than that maximally feasible is produced.
\end{abstract}

Material and methods: The effects of iron availability and chelation on PpIX-PDT have therefore been investigated via fluorescence quantification of PpIX accumulation, single-cell gel electrophoresis (comet assay) measurement of ROS-induced DNA damage and trypan blue exclusion assessment of cell viability. Cultured human cells were utilised and incubated in standardised iron conditions with the PpIX precursor's aminolaevulinic acid (ALA) or its methyl ester (MAL) in the presence or absence of either of the iron chelating agents desferrioxamine (DFO) or hydroxypyridinone (CP94), or alternatively iron sulphate as a source of iron.

Results: ALA or MAL incubation was found to significantly increase cellular PpIX accumulation pre-irradiation as anticipated and this observation correlated with both significantly increased DNA damage and reduced cellular viability following irradiation. Coincubation with either of the iron chelators investigated (DFO or CP94) significantly increased pre-irradiation PpIX accumulation as well as DNA damage and cell death on irradiation indicating the positive effect of iron chelation on the effectiveness of PpIXinduced PDT. The opposite effects were observed however, when the cells were co-incubated 
with iron sulphate, with significant reductions in pre-irradiation PpIX accumulation (ALA only) and DNA damage (ALA and MAL) being recorded indicating the negative effects excessive iron can have on PpIX-PDT effectiveness. Some dark toxicity produced by iron sulphate administration in non-irradiated control groups was also observed.

Conclusion: Iron chelation and availability have therefore been observed to positively and adversely affect the PpIX-PDT process respectively and it is concluded that the effects of increased PpIX accumulation pre-irradiation produced via iron chelation outweigh any limitations reduced iron availability may have on the ability of iron to catalyse ROS generation/cascades following PpIX-induced PDT. Further investigation of iron chelation within dermatological applications where enhanced PpIX-PDT treatment effects would be beneficial is therefore warranted.

Keywords: aminolaevulinic acid (ALA); 1,2-diethyl-3-hydroxypyridin-4-one hydrochloride (CP94); desferrioxamine (DFO); iron sulphate; methyl-aminolevulinate (MAL); reactive oxygen species (ROS).

\section{Zusammenfassung}

Hintergrund: Die Protoporphyrin IX (PpIX)-induzierte photodynamische Therapie (PDT) wird als topische Methode der lokalen Ablation von bestimmten Nicht-MelanomHautkrebsarten und Präkanzerosen genutzt. Standardisierte Protokolle resultieren in einer guten Wirksamkeit, wenn die betroffenen Areale oberflächlich begrenzt sind, erfordern aber eine Verbesserung bei der Behandlung dickerer und tiefer gelegener Läsionen. Es konnte gezeigt werden, dass die gleichzeitige Verabreichung eines Eisenchelators während der PpIXPDT die zelluläre Akkumulation von PpIX verbessert, indem die biologische Umwandlung zu Häm (ein Eisen-abhängiger Prozess) gehemmt wird, wodurch wiederum die Zelltötung bei der nachfolgenden Bestrahlung erhöht wird. Eisen kann jedoch auch eine Rolle bei der Erzeugung von reaktiven Sauerstoffspezies (ROS) spielen und deren Verfügbarkeit durch chemische Chelation verringern und zumindest theoretisch die Wirksamkeit der PpIX-PDT verschlechtern, so dass die Reaktion geringer ausfällt als die maximal mögliche Wirkung.

Material und Methoden: Es wurden die Auswirkungen der Eisenverfügbarkeit und Chelation auf die PpIX-PDT mittels Fluoreszenzquantifizierung der PpIX-Akkumulation, Einzelzell-Gelelektrophorese (Comet-Assay)-Messung der ROS-induzierten DNA-Schäden und Trypanblau-Ausschluss-Beurteilung der Zelllebensfähigkeit untersucht. Für die 
Experimente wurden kultivierte menschliche Zellen verwendet, die unter genormten Eisenbedingungen mit dem PpIX-Vorläufer Aminolävulinsäure (ALA) oder deren Methylester (MAL) in Gegenwart oder Abwesenheit von entweder den Eisenchelatbildnern Deferoxamin (DFO) bzw. Hydroxypyridinon (CP94) oder alternativ Eisensulfat als Eisenquelle inkubiert wurden.

Ergebnisse: Wie erwartet erhöhte die Inkubation der Zellen mit ALA oder MAL vor der Bestrahlung die zelluläre PpIX-Anreicherung signifikant, was mit der beobachteten deutlich reduzierten Zelllebensfähigkeit und den verstärkten DNA-Schäden nach der Bestrahlung korrelierte. Eine Co-Inkubation mit einem der untersuchten Eisenchelatoren (DFO oder CP94) erhöhte die PpIX-Anreicherung vor der Bestrahlung ebenfalls signifikant, ebenso wie DNA-Schäden und Zelltod bei Bestrahlung, was den positiven Effekt der Eisenchelation auf die Wirksamkeit der PpIX-induzierten PDT belegt. Die entgegengesetzten Effekte wurden jedoch beobachtet, wenn die Zellen zusammen mit Eisensulfat inkubiert wurden. Hier zeigten sich eine signifikante Abnahme der PpIX-Anreicherung vor Bestrahlung (nur bei ALA) und verminderte DNA-Schäden (bei ALA und MAL), was die negativen Auswirkungen eines übermäßigen Eisengehalts auf die Wirksamkeit der PpIX-PDT belegt. Darüber hinaus wurde in den nicht bestrahlten Kontrollgruppen, die mit Eisensulfat inkubiert wurden, eine gewisse Dunkeltoxizität registriert.

Fazit: Eisenchelation und Verfügbarkeit können sowohl positiven als auch negativen Einfluss auf das PpIX-PDT-Verfahren haben, jedoch kann aus den Untersuchungen geschlussfolgert werden, dass die durch die Eisenchelation erzielte verbesserte PpIX-Anreicherung vor der Bestrahlung die Beschränkungen einer durch Eisen reduzierten ROS-Verfügbarkeit während der PpIX-induzierte PDT überwiegt. Weitere Untersuchungen der Eisenchelation innerhalb dermatologischer Anwendungen, wo ein verbesserter Therapieerfolg nach PpIX-PDTBehandlung angestrebt wird, sind daher angezeigt.

Schlüsselwörter: Aminolävulinsäure (ALA); 1,2-Diethyl-3-Hydroxypyridin-4-on Hydrochlorid (CP94); Deferoxamin (DFO); Eisensulfat; Methyl-Aminolaevulinat (MAL); reaktive Sauerstoffspezies (ROS).

*Corresponding author: Alison Curnow, Knowledge Spa, Royal Cornwall Hospital, University of Exeter Medical School, Truro, Cornwall TR1 3HD, United Kingdom, e-mail: a.curnow@exeter.ac.uk

Andrew Pye: Knowledge Spa, Royal Cornwall Hospital, University of Exeter Medical 
School, Truro, Cornwall TR1 3HD, United Kingdom

DOI $\mathrm{xx}$

received August 21, 2014; revised October 8, 2014; accepted October 15, 2014, previously published online $\mathrm{xx}, 2014$

\section{Introduction}

Photodynamic therapy (PDT) requires three key components for a successful clinical effect a photosensitiser, activating light of a specific wavelength and molecular oxygen [1]. When combined concurrently in sufficient amounts these components result in the production of reactive oxygen species (ROS) and oxidative stress [2]. This process directly and indirectly damages cellular components leading to cell death through necrosis, apoptosis and/or autophagy depending on the type of photosensitiser employed, its subcellular localisation as well as the particular dose parameters utilised [3].

Protoporphyrin IX (PpIX)-induced PDT (PpIX-PDT) is utilised as topical method of localised ablation of certain non-melanoma skin cancers and precancers [4]. 5-Aminolevulinic acid (ALA)-induced photodynamic therapy (ALA-PDT) was first introduced experimentally by Malik and Lugaci in 1987 [5], with the first clinical treatments reported by Kennedy and coworkers in 1990 [6]. Within a clinical setting topical PpIX-PDT now involves the application of a cream formulation containing a PpIX precursor - usually ALA or its methyl ester (MAL) - to the area to be treated. The area is then covered with a light-occluding dressing for a number of hours (usually $3 \mathrm{~h}$ ) during which time the precursor is absorbed into the lesion and biochemically converted relatively rapidly by the diseased cells into the natural photosensitiser PpIX via haem biosynthesis. ALA or MAL applied in this way act as substrates for the production of haem and its precursors whilst avoiding the negative feedback loop that haem has on its own production. The intermediate immediately preceding haem in the haem biosynthesis pathway is PpIX and this accumulates following ALA or MAL administration because the last step of haem biosynthesis (the insertion of ferrous iron into the porphyrin ring of PpIX by ferrochelatase to form haem) [7] is relatively slow and is in fact the secondary rate limiting step of the pathway (the primary rate limiting step being the formation of ALA by ALA synthase which is bypassed by exogenous ALA/MAL administration). Haem is broken down by the enzyme haem oxygenase 1 (HO-1), a process by which iron is released. The level of cellular free iron is tightly controlled by homeostatic iron regulatory proteins 
which can either act by up-regulating the iron-sequestering protein ferritin or by up-regulating transferrin receptor synthesis [8]. These processes enable cells to respond to changes in iron concentration and regulate cellular labile iron levels as too little iron would adversely affect cell function, while too much free cellular iron could result in highly damaging metal catalysed ROS reactions. Iron therefore has a major and complex role in the production of PpIX during PpIX-induced PDT.

Once PpIX accumulation has occurred within the tumour cells in this manner, visible light matching both the absorption spectrum of the photosensitiser (PpIX) and the optimum wavelength for tissue transmission is applied to the tumour; normally $635 \mathrm{~nm}$ is utilised for all but the most superficial dermatological lesions and is frequently delivered using a lightemitting diode (LED) array [9]. PpIX absorbs energy from the light and enters a higher singlet energy state. This absorbed energy is then either released as fluorescence as the photosensitiser returns to the ground state or is transferred via intersystem crossing to the longer lived triplet state allowing more opportunity for energy to be transferred to nearby molecules in the cell. This transfer of energy from the triplet state can occur via type-I or type-II reactions. Type-II reactions involve the transfer of energy to oxygen to form singlet oxygen and this type of reaction is thought to predominate initially within the PpIX-PDT process [10]. Singlet oxygen can however subsequently transfer energy to other molecules resulting in the production of ROS cascades, which also serve to transmit damage further afield within the cell from the original site of initial photodynamic damage. If enough damage is produced within a cell, cell death can result [11] via necrosis, apoptosis and/or autophagy (the degradation of cellular components internally) [12-14]. Apoptosis has two major pathways (extrinsic and intrinsic) and during PpIX-induced PDT, the intrinsic pathway is thought to be more important due to PpIX localisation within mitochondria [15]. Damage to mitochondria or loss of the mitochondrial membrane potential as can occur during PDT, may lead to an excessive release of ROS into the cytoplasm. These ROS, as well causing direct damage, may also change the redox state of the cell and initiate/modulate ROS sensitive signalling cascades. The damage and ROS thus produced may then induce secondary damage to other cellular components (including DNA).

Clinically, substantial subsets of skin tumours exist which are relatively difficult to treat with conventional therapies such as surgery and cryotherapy because of their size, location or number within an area of field change [16]. PDT can be advantageous in these situations and is associated with excellent cosmesis making it a particularly attractive treatment option for cosmetically conspicuous sites [17]. Standardised topical PpIX-PDT protocols utilising both 
ALA (Ameluz, Spirit Healthcare, UK) and MAL (Metvix, Galderma, UK) have been implemented within dermatology to good effect when the disease remains superficial [18], but improvement is required to treat thicker or acrally located conditions [19]. Many adaptations to standard treatment have been considered to improve efficacy including skin pre-treatment with the malignant cell differentiation potentiator dimethyl sulfoxide [20], skin stripping with tape [21], light dose fractionation [22, 23], low fluence rate light administration [24] as well as combinations with other techniques such as low-dose Photofrin ${ }^{\circledR}$ [25], hyperthermia [26, 27], iontophoresis [28] and bioreductive drugs [29]. Concurrent administration of an iron chelator, such as ethylenediamine tetraacetic acid (EDTA) [30-33], desferrioxamine (DFO) [30, 34-37] or the novel hydroxypyridinone iron chelator 1,2-diethyl-3-hydroxypyridin-4-one hydrochloride (CP94) [38-43], during PpIX-PDT has also been demonstrated to increase cellular accumulation of PpIX by reducing its bioconversion to haem by ferrochelatase (an iron dependent process) thus increasing cell kill on subsequent irradiation. This method of enhancement is attractive because simply increasing the precursor dose or application time doesn't appear to produce cost efficacy or practical substantial improvements [44].

DFO has been demonstrated to be superior to EDTA in its ability to enhance PpIX-induced PDT [30] and in a separate investigation, CP94 has been found to be superior to DFO for this purpose [43]. CP94 is a member of the hydroxypyridinone family of oral iron chelators originally developed to supersede DFO in the treatment of iron overload, which has to be administered intravenously clinically via long infusion. CP94 is particularly effective at chelating intracellular iron and has a lower molecular weight and higher lipophilicity than either DFO or EDTA [45] and is well suited to augmenting dermatological PDT as it can be applied topically [46]. CP94 has already been demonstrated to enhance ALA-induced PpIX fluorescence [38] and to also produce greater tumour necrosis within animal models [41, 42]. CP94 has been investigated in a healthy skin explant model producing increased PpIX accumulation when employing either ALA or MAL as the PpIX precursor [39]. When the level of PpIX accumulation produced by DFO and CP94 were compared directly in vitro, these iron chelators in combination with ALA or MAL were shown to significantly increase the amount of PpIX accumulating within fetal lung fibroblasts (MRC-5 cells) and the more difficult-to-culture epidermal carcinoma cells (A431), whilst minimal enhancement was observed in the normal skin fibroblasts (84BR cell line) and normal human epidermal keratinocytes investigated. Where enhancement was observed, CP94 was consistently demonstrated to be significantly superior to DFO in the production of elevated PpIX levels [43]. Furthermore, additional studies undertaken with CP94 alone within A431 cells have 
indicated that significantly increased PpIX levels and subsequent cytotoxicity can be produced when using HAL (the hexyl ester of ALA) as well as ALA or MAL as the PpIX precursor, when PDT is conducted within a variety of different oxygen conditions [47].

Clinically Fijan et al. [35] has demonstrated the feasibility of combining the iron chelator DFO with ALA-PDT to treat 34 superficial basal cell carcinomas (BCCs) and 22 nodular BCCs with ALA. Liu et al. [32] and Choudry et al. [34] have also investigated EDTA and DFO respectively in humans, utilising matched skin lesion controls. Lui et al. [32] found a promising and significant $(p<0.01)$ reduction in tumour depth in lesions treated with EDTA in combination with ALA-PDT. Choudry et al. [34] however, could not detect any significant differences in surface fluorescence between lesions co-incubated with ALA \pm DFO. Two clinical pilot studies of CP94 in combination with ALA or MAL-induced PDT have been conducted to date and have demonstrated the safety and feasibility of this treatment modification [48, 49]. Although these clinical investigations were only designed to assess safety, enhancements in tumour clearance were observed both clinically and histologically when CP94 was included within the photosensitising cream.

However, due to its multiple valences, iron can also play an important role in ROS biology [50] and has the potential to increase cytotoxicity from PDT. Iron is important in the generation of the hydroxyl radical as well as in lipid peroxidation [51]. Singlet oxygen generated by PpIX-induced PDT can itself react with oxygen to generate superoxide. Superoxide is fairly stable under physiological conditions and does not readily react with other biomolecules, but its ability to generate further, more reactive ROS, makes it toxic. Superoxide is dismutated by superoxide dismutase within cells to form hydrogen peroxide, which readily diffuses through membranes (due to its uncharged nature and poor reactivity). Hydrogen peroxide is detoxified via catalase to produce water and oxygen. However if hydrogen peroxide comes into contact with metal ions (especially $\mathrm{Fe}^{2+}$ ) then the highly reactive hydroxyl radical can be formed via Fenton reactions and this can lead to damage of cellular proteins, lipids and DNA [52]. Limiting the availability of iron via chemical chelation could therefore theoretically reduce the efficacy of PpIX-PDT by blocking or limiting this hydroxyl radical generating pathway so that a response less than that maximally feasible was produced by the treatment. The effects of iron availability and chelation on PpIX-PDT have therefore been investigated in detail here for the first time within cultured human cells incubated in standardised iron conditions with ALA or MAL in the presence or absence of either of the iron chelating agents DFO or CP94, or alternatively iron sulphate as a source of iron. 


\section{Material and methods}

\subsection{Cell culture}

All media and disposable plastic equipment were purchased from Sigma (Poole, UK) unless otherwise stated. Human MRC-5 cells were obtained from the European Collection of Cell Cultures (ECACC, Wiltshire, UK). Cells were maintained in Eagle's minimum essential medium (EMEM) supplemented with $10 \%$ iron standardised fetal calf serum (FCS), i.e. standardised to give an iron concentration between 450-600 $\mu \mathrm{g} / 100 \mathrm{~g}, 2 \%$ (200 mM) Lglutamine, $2 \%(200 \mathrm{U} / \mathrm{ml})$ penicillin and $(200 \mu \mathrm{g} / \mathrm{ml})$ streptomycin solution. Cells were grown in $5 \% \mathrm{CO}_{2}$ at $37^{\circ} \mathrm{C}$.

It should be noted that the utilisation of FCS that consistently contained a specific amount of iron throughout the experimentation was an important aspect of the experimental design adopted for this investigation. This was important as most commercial sources of FCS contain varying and unspecified quantities of iron, which would not permit the effect of adding specific concentrations of iron sulphate to the cell cultures to be elucidated within the study nor in fact the effect of the iron chelator being investigated. Initial studies (data not shown) both with and without the presence of an iron chelating agent, also indicated that PpIX levels were observed to be greater without the addition of FCS to the cell culture media (i.e. without this source of iron being present).

\subsection{Cell and solution preparation}

Before conducting PpIX fluorescence measurements cell viability was assessed using trypan blue exclusion. Cell viability was $>98 \%$ for all experimentation. Cells were seeded into the wells of 96-well plates (Corning, flat bottom, cell culture treated) at a density of $10^{4}$ cells per well (i.e. $100 \mu \mathrm{l}$ of a $10^{5}$ cell/ml solution was added to each well) and incubated overnight at $37^{\circ} \mathrm{C}$ in $5 \% \mathrm{CO}_{2}$. At these densities cells just reached confluence after the overnight incubation. The following day all media were removed and the cells washed with phosphatebuffered saline (PBS). All test solutions were freshly prepared before each experiment by dissolving ALA, MAL, CP94, DFO or iron sulphate into modified EMEM (minus phenol red) with $10 \%$ iron standardised FCS. The $\mathrm{pH}$ of the solutions were checked and adjusted to physiological $\mathrm{pH}(\mathrm{pH} 7.4)$ using $\mathrm{NaOH}(0.5 \mathrm{M})$ as necessary. Solutions were then filter sterilised $(0.22 \mu \mathrm{m}$, Millipore filter) before being diluted to the final concentrations utilised. CP94 was kindly provided as a powder by Professor Hider (King's College London, UK). 


\subsection{Initial PpIX measurements}

Initially an ALA or MAL concentration experiment was conducted, i.e. $0,100 \mu \mathrm{M}, 200 \mu \mathrm{M}$, $300 \mu \mathrm{M}, 400 \mu \mathrm{M}, 500 \mu \mathrm{M}$ and $1000 \mu \mathrm{M}$ ALA or MAL concentrations were employed utilising $1000 \mu \mathrm{M}$ control groups for both congeners (Figures 1 and 2 respectively). Here, greater absolute levels of PpIX accumulated in the ALA-treated cells compared to the MALtreated cells were found. For this reason concentrations of $500 \mu \mathrm{M}$ ALA (producing 248 a.u. mean PpIX fluorescence in the subsequent experimentation) and $1000 \mu \mathrm{M}$ MAL (producing 221 a.u. mean PpIX fluorescence in the subsequent experimentation) were employed for the later experiments (with $500 \mu \mathrm{M}$ ALA (Figures 3, 5 and 7) and $1000 \mu \mathrm{M}$ MAL (Figures 4, 6 and 8) control groups utilised respectively) so that similar levels of PpIX were generated by each congener at baseline (without the addition of iron or the respective iron chelators).

\subsection{PpIX fluorescence assessments}

During and after the addition of the test solutions all procedures were carried out under reduced light levels (luminance in the laboratory was reduced to $50 \mathrm{~lx}$ ) to reduce photobleaching of the metabolised PpIX molecule. PpIX fluorescence was measured using a fluorescence plate reader (Synergy HT; BioTek, Germany). Measurements were made after an incubation period of $6 \mathrm{~h}$ with the test solutions. During this time cells were incubated in the dark in a $5 \% \mathrm{CO}_{2}$ incubator at $37^{\circ} \mathrm{C}$. A second PpIX fluorescence measurement was also made following light irradiation. The plate reader was pre-heated to $37^{\circ} \mathrm{C}$ to reduce temperature-edge effects. Measurements were taken with a $400 \pm 30 \mathrm{~nm}$ excitation filter and a $645 \pm 40 \mathrm{~nm}$ emission filter from the bottom of the plate. The sensitivity of this system set-up had previously been tested in our laboratory using commercially sourced pre-synthesised PpIX (Sigma, UK). PpIX fluorescence was detected down to $75 \mathrm{pM}$ of pre-synthesised PpIX [43]. PpIX was shown to be the main fluorophore detected from ALA or MAL-incubated MRC-5 cells by measuring the absorbance spectra of MRC-5 cells incubated with ALA or MAL and comparing these spectra to that of the pre-synthesised PpIX (as previously published [43]). Each test plate contained control cells not incubated with any of the test solutions. These were used to remove background fluorescence from the data sets obtained (blanking). Each plate also contained plate control wells containing cells incubated with 500 or $1000 \mu \mathrm{M}$ ALA or MAL without either iron or the iron chelating agents to give a "standard plate control' level of PpIX production for comparison with iron chelator experimental groups. All PpIX fluorescence data are presented as a mean percentage \pm the standard 
deviation (SD) of the PpIX production of these control cells in order to eliminate any effects of plate-to-plate variation on these data. A minimum of three readings were made for each data point presented. Statistical significance was determined using a one-way ANOVA at a 95\% confidence level.

\subsection{Light irradiation}

After the initial PpIX measurements had been recorded, cells were irradiated using an Aktilite CL128 lamp with LEDs (Galderma, Hertfordshire, UK) at a distance of $5 \mathrm{~cm}$ and for a period of $3 \mathrm{~min}$. This is a commercially available LED light source that delivered $15 \mathrm{~J} / \mathrm{cm}^{2}$ of red light $\left(635 \pm 2 \mathrm{~nm} ; 75 \mathrm{~mW} / \mathrm{cm}^{2}\right)$ to the plates. Dark control plates were also removed from the incubator in parallel and left in the dark on the bench for $3 \mathrm{~min}$. Further fluorescence readings were taken from these irradiated and non-irradiated plates.

\subsection{Determination of cell viability}

Trypan blue exclusion was employed to determine cell viability. Following irradiation with the Aktilite $128 \mathrm{LED}$ array (as above) plates were incubated overnight in a $5 \% \mathrm{CO}_{2}$ incubator at $37^{\circ} \mathrm{C}$. The following day the wells were washed with PBS, and $100 \mu 1$ trypan blue dye was added to the wells. The dye was left for 3 min before being removed. The number of viable and non-viable adherent cells present in each well was then ascertained and the total viability was calculated by combining triplicate readings and presenting the data set as the mean percentage of the non-treated control wells $( \pm S D)$.

\subsection{Single cell gel electrophoresis}

Confluent MRC-5 cells were incubated overnight in a $5 \% \mathrm{CO}_{2}$ incubator at $37^{\circ} \mathrm{C}$ in $\mathrm{T} 25 \mathrm{~cm}^{2}$ tissue culture flasks with the test solutions (ALA/MAL, the iron chelators DFO or CP94, or alternatively iron sulphate). The following day cells were processed onto CometSlides (Trevigen, USA) using an alkali single cell gel electrophoresis protocol modified by Morley et al. [53] and originally described by Singh et al. [54]. Cells were then irradiated using the Aktilite $128 \mathrm{LED}$ array at a distance of $5 \mathrm{~cm}$ and for a period of $3 \min \left(15 \mathrm{~J} / \mathrm{cm}^{2} ; 635 \pm 2 \mathrm{~nm}\right.$; $75 \mathrm{~mW} / \mathrm{cm}^{2}$ ). Non-irradiated controls for each concentration were kept in the dark during this period. After irradiation, sample and corresponding dark control slides were immediately transferred to lysis buffer for $40 \mathrm{~min}$ (to minimise DNA repair), followed by transfer to unwinding buffer $(\mathrm{pH}>13$, incubated for $40 \mathrm{~min}$ ) and electrophoresis ( $24 \mathrm{~min}$ at $20 \mathrm{~V}, 200$ 
$\mathrm{mA}$ ) according to the protocol described by Morley et al. [53]. Slides were then placed in $100 \%$ ethanol for dehydration. Following overnight drying, slides were stained using 10 $\mu \mathrm{g} / \mathrm{ml}$ ethidium bromide and the DNA visualised using a fluorescence microscope (Versus; Ceti, Antwerp, Belgium). Image analysis software (Comet Assay II; Perceptive Instruments, Surrey, UK) was then used to analyse 60 comets from each sample area (2 sample areas per slide, 240 comets scored per variable). These data were found to be non-parametric therefore the Mann-Whitney rank sum test was used to make statistical comparisons between the median values from the test and control cells. Data were presented as box-and-whisker plots where the median value was illustrated as a line flanked by boxes within which $25 \%$ to $75 \%$ of the data fell and whiskers indicating $10 \%$ to $90 \%$ of the data range observed. In a cell culture study Duez et al. [55] concluded that analysis of median comet data from repeated experiments is an efficient way to demonstrate genotoxic effects with ALA [55].

\section{Results}

\subsection{ALA/MAL alone PpIX fluorescence: DNA damage and cell viability}

Throughout all experiments similar trends were observed whether ALA or MAL was employed. Pre-irradiation PpIX fluorescence increased with increasing concentrations of both ALA (Figure 1A) and MAL (Figure 2A). Irradiation of the cells with red light $\left(15 \mathrm{~J} / \mathrm{cm}^{2}\right.$ ) resulted in photobleaching of the ALA/MAL-induced PpIX and a subsequent significant drop $(p<0.05)$ in the level of PpIX fluorescence observed (Figures 1A and 2A). As anticipated this photobleaching was not observed in the non-irradiated controls (Figures 1B and 2B).

The cellular damage (in the form of DNA damage) observed after light irradiation in the ALA or MAL-treated MRC-5 cells (Figures 1C and 2C respectively) increased with increasing preirradiation PpIX levels and post irradiation photobleaching, with no significant DNA damage being measured in the non-irradiated controls (Figures 1D and 2D). No statistically significant increases in DNA damage were also detected following irradiation after incubation with the lowest doses of ALA $(\leq 300 \mu \mathrm{M})$ or $\mathrm{MAL}(\leq 400 \mu \mathrm{M})$ but DNA damage increased in a concentration dependent manner with concentrations above $300 \mu \mathrm{M}$ ALA and $400 \mu \mathrm{M}$ MAL respectively (Figures $1 \mathrm{C}$ and $2 \mathrm{C}$ ).

At the highest concentrations of ALA investigated DNA damage was at the upper limit of that detectable using the comet assay (Figure 1C). The level of damage detected in the MALtreated cells (Figure 2C) was slightly lower than that detected with corresponding concentrations in the ALA-treated cells. This was reflected by the levels of PpIX detected 
with ALA and MAL, with MAL-incubated cells accumulating less PpIX than their ALAtreated counterparts (Figures $2 \mathrm{~A}$ and $1 \mathrm{~A}$ respectively). In the subsequent iron and iron chelator experiments the concentration of ALA used was therefore lowered from $1000 \mu \mathrm{M}$ to $500 \mu \mathrm{M}$ to account for the differences in PpIX accumulation between ALA and MAL and to reduce the level of DNA damage to a level detectable by the comet assay.

The post irradiation cell viability of the ALA or MAL-treated MRC-5 cells (Figures 1E and 2E) was inversely related to the levels of pre-irradiation PpIX fluorescence (Figures 1A and 2A) detected and DNA damage (Figures 1C and 2C). This effect was not observed within the non-irradiated controls where viability remained high (Figures $1 \mathrm{~F}$ and $2 \mathrm{~F}$ ). These observations collectively indicated that high levels of PpIX accumulation pre-irradiation, followed by PpIX photobleaching and increased DNA damage post irradiation were associated with reduced cell viability suggesting that PpIX-PDT cytotoxicity was related to the oxidative damage produced on irradiation and that PpIX accumulation alone (without light exposure) was not genotoxic. A significant reduction in cellular viability was however observed in the non-irradiated $500 \mu \mathrm{M}$ MAL-treated cells possibly denoting some slight dark toxicity of this compound at the higher concentrations investigated.

The fractionally reduced PpIX levels post sham irradiation in the non-irradiated controls was probably the result of some minor bleaching of the PpIX molecule occurring due to exposure of the cells to ambient light during the sham irradiation process and/or the excitation light from the plate reader. The non-significant nature of the bleaching observed indicated that the measures taken to reduce photobleaching (such as the reduction of laboratory lighting levels) were adequate and did not substantially adversely affect the results recorded within the irradiated groups.

\subsection{ALA/MAL plus DFO PpIX fluorescence: DNA damage and cell viability}

Co-incubation of ALA or MAL with the iron chelating agent DFO resulted in significantly $(p<0.05)$ increased levels of PpIX detected compared to that detected in ALA or MAL-only treated MRC-5 cells (Figures 3A and 4A respectively) however over the dose range investigated (50-300 $\mu \mathrm{M}$ DFO) the PpIX levels generated remained relatively consistent despite the variation in iron chelator dose. As observed in Figures 1 and 2, irradiation resulted in significant photobleaching $(p<0.05)$ (Figures 3A and 4A) and this was not observed in the non-irradiated controls (Figures 3B and 4B).

The DNA damage observed in the ALA+DFO co-incubated cells following irradiation was consistently significantly higher than in the ALA-only treated cells $(p<0.05)$ (Figure 3C). 
However only the $150 \mu \mathrm{M}$ DFO+MAL-treated cells had levels of DNA damage that were statistically higher than the MAL-only treated cells $(p<0.05)$ (Figure 4C). With both congeners no DNA damage above background levels was observed when no irradiation was delivered (Figures 3D and 4D).

Cell viability was significantly reduced in both ALA and MAL-treated cells following irradiation $(p<0.05)$ (Figures $3 \mathrm{E}$ and $4 \mathrm{E}$ respectively). In the non-irradiated cells cell viability was not significantly reduced (Figures $3 \mathrm{~F}$ and $4 \mathrm{~F}$ ) in any of the treatment groups investigated. These findings indicate that similar mechanistic processes of cellular damage and death appear to be occurring during PpIX-induced PDT with and without the iron chelator, DFO.

\subsection{ALA/MAL plus CP94 PpIX fluorescence: DNA damage and cell viability}

Co-incubation of both ALA and MAL with CP94 resulted in relatively consistent significant enhancements in the level of pre-irradiation PpIX fluorescence detected $(p<0.05)$ (Figures 5A and 6A respectively). Again significant photobleaching of PpIX fluorescence was only observed following irradiation (Figures $5 \mathrm{~A}$ and $6 \mathrm{~A}$ ) but not in the non-irradiated controls (Figures 5B and 6B).

The subsequent DNA damage observed after light irradiation in the CP94 co-incubated cells (Figures 5C and 6C) was once again related to the pre-irradiation levels of PpIX with greater levels of PpIX fluorescence pre-irradiation being associated with greater DNA damage following irradiation. The DNA damage observed in these CP94 co-incubated cells was significantly $(p<0.05)$ higher than in the ALA or MAL-only $(0 \mu \mathrm{M}$ CP94) treated cells at all CP94 concentrations investigated (Figures 5C and 6C respectively). The level of DNA damage detected in the non-irradiated ALA or MAL-treated cells (Figures 5D and 6D respectively) was much lower than that detected in the irradiated cells (Figures 5C and 6C). This level of damage was at the expected background level of DNA damage for this cell type as observed in previous experimentation (data not shown).

As observed with DFO, cell viability was also reduced by the administration of CP94 in the irradiated cells (Figures 5E and 6E) but remained high in the non-irradiated cells (Figures 5F and $6 \mathrm{~F}$ ) with either ALA or MAL incubation in all cases except for the highest dose of ALA investigated which fell but in a non-statistically significant manner (Figure 5F). It is also interesting to note that within the irradiated groups the level of DNA damage produced by PpIX-PDT recorded with CP94 appeared a little greater than with DFO, whereas the reverse trend was observed with cell viability. On the whole both iron chelating agents actually performed in a similar manner, which is of note as being bidentate, three times the amount of 
CP94 should be required to chelate the same quantity of iron as multidentate DFO.

\subsection{ALA/MAL plus iron sulphate PpIX fluorescence: DNA damage and cell viability}

The mean level of PpIX fluorescence detected pre-irradiation in the ALA+iron sulphate coincubated cells decreased in a concentration dependent manner with increasing iron sulphate concentration $(p<0.05)$ (Figure 7A). This was in sharp contrast to the opposite effect observed with the iron-chelated cells (ALA+DFO, Figure 3A; and ALA+CP94, Figure 5A) and highlights the importance of the limiting role of iron availability has on PpIX accumulation (by facilitating haem synthesis) and supports the hypothesis that the iron chelators investigated mediated their effects through sequestering iron to reduce the conversion of PpIX to haem resulting in elevated PpIX accumulation. Again the application of light to the cells resulted in significant PpIX photobleaching $(p<0.05)$ (Figure 7A), an effect not substantially observed in the non-irradiated controls (Figure 7B).

On irradiation a significant concentration dependent decrease in DNA damage $(p<0.05)$ occurred with increasing iron sulphate concentration (Figure 7C). This was consistent with the level of PpIX initially detected within the cells pre-irradiation (Figure 7A) and suggested that the limiting effect of iron availability on PpIX accumulation had a greater (negative) effect on the level of DNA damage produced than the potential (positive) role that iron may have had catalysing the ROS cascades that occur subsequent to PpIX-PDT. It therefore appears to be more beneficial to chelate iron (Figures 3, 4, 5 and 6) rather than supplement it (Figures 7 and 8) when trying to improve PpIX-PDT (Figures 1 and 2) treatment effects. Interestingly in the non-irradiated iron sulphate-treated cells $(10-100 \mu \mathrm{M})$, DNA damage increased significantly $(p<0.05)$ above that observed with the $0 \mu \mathrm{M}$ control group (Figure 7D) (albeit to a much smaller degree than observed in the irradiated cells; Figure 7C), reiterating the importance of the normal homeostatic processes of tight cellular control of iron levels to reduce the oxidative damage that can be catalysed by the availability of this transition metal. This effect of additional iron supply was also observed in the corresponding viability experiments (Figure 7F) but cell viability was reduced to a much greater extent following irradiation and appeared to be relatively consistent at all iron sulphate concentrations investigated (Figure 7E).

In the MAL+iron sulphate co-incubated cells there was no significant difference in the level of PpIX detected in the cells with increasing iron concentrations either with (Figure 8A) or without irradiation (Figure 8B). This suggested that the process of conversion of PpIX to haem was already operating at a maximal rate with this particular concentration of MAL and 
was not being limited by iron availability (therefore iron supplementation made very little impact on PpIX accumulation). A significant $(p<0.05)$ reduction in DNA damage was however observed in the $10 \mu \mathrm{M}$ and $100 \mu \mathrm{M}$ iron sulphate co-incubated cells (Figure 8C). However this reduction in DNA damage observed with MAL (Figure 8C) had no obvious trend and was less pronounced than that observed in the ALA co-incubated cells (Figure 7C) and therefore was in general agreement with the unaltered MAL-PpIX accumulation observed with increasing concentrations of iron sulphate in Figure 8A. Again as observed in the ALA+iron sulphate-treated cells, DNA damage was very slightly higher in the non-irradiated MAL-treated cells incubated in the presence of iron sulphate (Figure 8D). Once again cell viability was significantly reduced in the light irradiated MAL+iron sulphate-incubated cells (Figure 8E) but remained high in the non-irradiated MAL+iron sulphate-treated cells (Figure $8 \mathrm{~F}$ ) with very little difference being observed with the varying concentrations of iron sulphate investigated here (which again was in agreement with the unaltered MAL-induced PpIX levels observed with increasing concentrations of iron sulphate in Figure 8A).

\section{Discussion}

These findings demonstrate the importance of the role of iron within the mechanism of PpIXinduced PDT. The changes in damage seen with different iron levels were predominantly related to the accumulation of PpIX pre-irradiation, with higher levels of PpIX and subsequent cellular damage/death observed in the iron chelator-treated cells (Figures 3, 4, 5 and 6).

Less absolute PpIX fluorescence was detected in the MAL-treated cells (Figure 2) compared to that of the ALA-treated cells (Figure 1). It is thought that once absorbed the methyl group of MAL is liberated in the cell by non-specific esterases. This extra enzyme step may have reduced the overall rate of accumulation of PpIX in our cellular system. Alternatively differences in the rate of uptake by the MRC-5 cells may have accounted for this difference. Because of the disparity in the levels of PpIX generated by ALA and MAL in this investigation concentrations of $500 \mu \mathrm{M}$ ALA and $1000 \mu \mathrm{M}$ MAL were employed, so that roughly similar levels of PpIX were generated by ALA or MAL incubation without coincubation with the iron chelators or iron (this also meant that the subsequent levels of DNA damage generated were within the optimal range for detection via single cell gel electrophoresis).

When light was applied, significant photobleaching of the PpIX molecule was observed. This 
was as expected and similar photobleaching is observed with ALA-PDT in vivo [24]. Photobleaching of PpIX has previously been shown to be a good indicator of photodynamic effect, and is light and oxygen dependent [56]. The level of PpIX photobleaching produced by light irradiation in this investigation was related to the subsequent level of DNA damage detected.

Co-incubation with the iron chelators (Figures 3, 4, 5 and 6) resulted in significantly increased levels of PpIX being detected compared to the ALA/MAL-only treated control cells with either congener employed. This finding supports previously published work in this area [30, 38, 43], furthermore being conducted in an iron controlled/standardised environment here. When activated by light these higher levels of PpIX resulted in increased cellular damage (as measured via DNA damage). This DNA damage was light dependent and was associated with reduced cell viability (as determined by trypan blue exclusion). DNA damage (using the Comet assay) has previously been reported in normal fibroblasts exposed to ALA-PDT (using a single ALA dose of $1 \mathrm{mM}$ ) [57]. Our results support these findings and extend them to also consider a greater number of ALA concentrations as well as iron supplementation/chelation with both DFO and CP94 and the methyl ester of ALA as a PpIX precursor.

More recently Chu and co-workers [58] have reported ALA-PDT-mediated DNA damage measured using the Comet assay. In contrast to Haylett et al. [57], Chu et al. [58] reported that no significant DNA damage could be detected in nasopharyngeal carcinoma cells using the Comet assay (despite these cells being treated with the same concentration of ALA, $1 \mathrm{mM}$, as those used by Haylett et al. [57]). Chu et al. [58] however commenced the Comet assay $24 \mathrm{~h}$ after irradiation and it was previously demonstrated by Haylett et al. [57] that cells can repair DNA fully within this time and so in the investigation reported here, DNA damage was assessed immediately following irradiation.

It should be noted that the Comet assay is a quantitative measure of strand breaks and does not give information on the type of damage or qualitative nature of repair. It has previously been reported however that ALA-PDT specifically results in an increase in 8-oxo-7,8dihydro-2'-deoxyguanosine (a mutagenic marker for oxidative damage) [59]. This would fit the current understanding of ALA-PDT-mediated DNA damage as an essentially ROSmediated process. Following PDT several of the enzymes involved in ROS detoxification e.g. manganese superoxide dismutase [60] and gamma-glutamylcysteine synthetase (the enzyme that catalyses the rate limiting step of glutathione synthesis) [61] have also been reported to have been up-regulated. DNA strand breaks can also result from apoptosis, which has also been observed to occur following ALA-PDT [62]. However as the Comet assay was 
performed immediately following light irradiation in this investigation, apoptosis would not be expected to occur in this short time period. Therefore although it is clear from the findings presented here that DNA damage did occur immediately following PpIX-PDT, further experimentation will be required to conclusively demonstrate that this was the result of oxidative stress and no other process.

However it is known that iron can also play an important role in ROS biology and has the potential to increase cytotoxicity from PDT. This has been previously demonstrated in vitro where cells were incubated with iron either before or after light irradiation [64]. Iron-beforelight irradiation resulted in less PpIX accumulating from the ALA pro-drug employed and a subsequent drop in lethality (as also observed here). Adding iron after irradiation increased lethality [63] and this aspect was not considered by the present study as such a manipulation would not be clinically practical.

The purpose of the investigation reported here was to further understand the effect of iron chelation and iron availability on the overall level of PpIX accumulation and cell damage/death detected during PpIX-PDT. The association between PpIX accumulation and cellular damage (in the form of DNA damage) and cell viability was the focus, rather than any repair that may occur as the result of any (sub-lethal) cellular damage produced by the treatment protocols employed or likewise the mode of cell death induced. Although DNA damage immediately following irradiation was observed there is no suggestion that this would be persistent or mutagenic in nature (although this possibility is theoretically feasible). Additionally as therapeutic PpIX-PDT treatments are designed to be cytotoxic, any DNAdamaged cells would not be expected to survive the treatment and new carcinogenesis within treatment fields has not been reported clinically during follow-up periods following licensed dermatological PpIX-PDT applications [64]. It is therefore very interesting to note that the significant increases in DNA damage observed here with ALA and MAL (Figures 1C and 2C respectively) started to occur at concentrations (400 $\mu \mathrm{M}$ ALA and $500 \mu \mathrm{M}$ MAL) where the corresponding cellular cytotoxicity was observed to be reaching approximately $50 \%$ (Figures $1 \mathrm{E}$ and $2 \mathrm{E}$ respectively). Our findings have suggested that the role of limited iron levels in elevating PpIX accumulation has a greater effect on the level of cellular damage produced by PpIX-induced PDT than the role of excess iron availability in the formation of ROS (as the level of damage/death was related to the differences in the accumulation of PpIX observed). A possible explanation for this may be that other transition metals (such as zinc or copper) may have mediated Fenton-type reactions instead of iron in the ROS cascades triggered by PpIXPDT. Having free iron available may have therefore not been crucial for this purpose and it is 
also likely that iron-mediated Fenton reactions are only a small part of a much larger mechanism of damage mediated by PpIX-induced PDT which is known to be originally initiated by type-II singlet oxygen production [65]. Furthermore, although cellular iron levels are tightly regulated under normal circumstances, during oxidative stress iron homeostasis can be disrupted resulting in the release of labile iron [66-68]. This may also partially explain our findings, so that iron chelation initially reduces iron availability so that PpIX accumulation during PpIX-PDT is elevated and once a state of oxidative stress begins to occur on irradiation other transition metals and freshly released labile iron perpetuate the ROS cascades via Fenton reactions. This hypothesis will however require further experimentation to conclusively ascertain.

Interestingly where pre-synthesised PpIX has been administered to cells, it has previously been demonstrated [63] that the addition of iron can increase cell kill (the opposite effect to that observed here). In this scenario however, iron-mediated ROS reactions would be much more important as the iron applied would not affect the level of PpIX located within the mitochondria of the cell but instead is thought to catalyse the reduction of lipid hydroperoxides resulting in free radial lipid peroxidation of the cell membrane.

This current study therefore highlights the important role of iron in the formation of cellular damage/death in ALA and MAL-PDT both with (Figures 3, 4, 5 and 6) and without the presence of an iron chelator (Figures 1 and 2). The enhancements in PpIX fluorescence detected in the DFO and CP94 co-incubated cells were translated into greater cellular DNA damage and subsequently greater cell death, presumably through the iron chelators' ability to limit free iron in the cellular system thus inhibiting the final step of haem biosynthesis, resulting in the higher levels of PpIX observed in these experiments pre-irradiation. Conversely co-incubation of iron with ALA/MAL-treated cells (Figures 7 and 8) resulted in lower PpIX pre-irradiation levels being detected, and subsequently following irradiation, lower levels of cellular damage and increased cell viability being observed.

\section{Conclusion}

In conclusion, iron chelation and availability during PpIX-PDT has been demonstrated to be an important aspect of this complex biochemical treatment process and the effects of increased PpIX accumulation pre-irradiation produced via iron chelation appear to be more crucial than having free iron available to catalyse the oxidative PpIX-PDT induced ROS cascades that ensue. Furthermore, the ability of the iron chelating agents investigated here 
(DFO and CP94) to increase the accumulation of pre-irradiation PpIX levels during ALA/MAL-induced PDT, enabled greater levels of cellular DNA damage and cell death to be generated upon irradiation. Additional investigations into the clinical application of concomitant iron chelation during PpIX-PDT (particularly with topically available iron chelating compound, CP94) would therefore be beneficial in order to determine whether a more effective treatment protocol could be derived in this manner for dermatological applications that currently require some improvement in efficacy.

Acknowledgements: The kind financial support of the Duchy Health Charity Limited, Cornwall, UK is very gratefully acknowledged.

\section{References}

[1] Henderson BW, Dougherty TJ. How does photodynamic therapy work? Photochem Photobiol 1992;55(1):145-57.

[2] Luna MC, Ferrario A, Wong S, Fisher AM, Gomer CJ. Photodynamic therapymediated oxidative stress as a molecular switch for the temporal expression of genes ligated to the human heat shock promoter. Cancer Res 2000;60(6):1637-44.

[3] Buytaert E, Dewaele M, Agostinis P. Molecular effectors of multiple cell death pathways initiated by photodynamic therapy. Biochim Biophys Acta 2007;1776(1):86-107.

[4] Morton CA, Szeimies RM, Sidoroff A, Braathen LR. European guidelines for topical photodynamic therapy part 1: treatment delivery and current indications - actinic keratoses, Bowen's disease, basal cell carcinoma. J Eur Acad Dermatol Venereol 2013;27(5):536-44.

[5] Malik Z, Lugaci H. Destruction of erythroleukaemic cells by photoactivation of endogenous porphyrins. Br J Cancer 1987;56(5):589-95.

[6] Kennedy JC, Pottier RH, Pross DC. Photodynamic therapy with endogenous protoporphyrin IX: basic principles and present clinical experience. J Photochem Photobiol B 1990;6(1-2):143-8.

[7] Dailey HA. Enzymes of heme biosynthesis. J Biol Inorg Chem 1997;2:411-7.

[8] Pourzand C, Watkin RD, Brown JE, Tyrrell RM. Ultraviolet A radiation induces immediate release of iron in human primary skin fibroblasts: the role of ferritin. Proc Natl Acad Sci USA 1999;96(12):6751-6. 
[9] Ericson MB, Wennberg AM, Larkö O. Review of photodynamic therapy in actinic keratosis and basal cell carcinoma. Ther Clin Risk Manag 2008;4(1):1-9.

[10] Castano AP, Demidova TN, Hamblin MR. Mechanisms in photodynamic therapy: part one-photosensitizers, photochemistry and cellular localization. Photodiagnosis Photodyn Ther 2004;1(4):279-93.

[11] Plaetzer K, Kiesslich T, Oberdanner CB, Krammer B. Apoptosis following photodynamic tumor therapy: induction, mechanisms and detection. Curr Pharm Des 2005;11(9):1151-65.

[12] Mroz P, Yaroslavsky A, Kharkwal GB, Hamblin MR. Cell death pathways in photodynamic therapy of cancer. Cancers (Basel) 2011;3(2):2516-39.

[13] Kessel D, Vicente MG, Reiners Jr JJ. Initiation of apoptosis and autophagy by photodynamic therapy. Autophagy 2006;2(4):289-90.

[14] Kessel D, Vicente MG, Reiners Jr JJ. Initiation of apoptosis and autophagy by photodynamic therapy. Lasers Surg Med 2006;38(5):482-8.

[15] Zhuang S, Demirs JT, Kochevar IE. Protein kinase C inhibits singlet oxygen-induced apoptosis by decreasing caspase-8 activation. Oncogene 2001;20(46):6764-76.

[16] Morton CA, McKenna KE, Rhodes LE; British Association of Dermatologists Therapy Guidelines and Audit Subcommittee and the British Photodermatology Group. Guidelines for topical photodynamic therapy: update. $\mathrm{Br} \mathrm{J}$ Dermatol 2008;159(6):1245-66.

[17] Svanberg K, Andersson T, Killander D, Wang I, Stenram U, Andersson-Engels S, Berg R, Johansson J, Svanberg S. Photodynamic therapy of non-melanoma malignant tumours of the skin using topical delta-amino levulinic acid sensitization and laser irradiation. Br J Dermatol 1994;130(6):743-51.

[18] Dirschka T, Radny P, Dominicus R, Mensing H, Brüning H, Jenne L, Karl L, Sebastian M, Oster-Schmidt C, Klövekorn W, Reinhold U, Tanner M, Gröne D, Deichmann M, Simon M, Hübinger F, Hofbauer G, Krähn-Senftleben G, Borrosch F, Reich K, Berking C, Wolf P, Lehmann P, Moers-Carpi M, Hönigsmann H, WernickePanten K, Helwig C, Foguet M, Schmitz B, Lübbert H, Szeimies RM; AK-CT002 Study Group. Photodynamic therapy with BF-200 ALA for the treatment of actinic keratosis: results of a multicentre, randomized, observer-blind phase III study in comparison with a registered methyl-5-aminolaevulinate cream and placebo. $\mathrm{Br} \mathrm{J}$ Dermatol 2012;166(1):137-46.

[19] Tyrrell JS, Morton C, Campbell SM, Curnow A. Comparison of protoporphyrin IX 
accumulation and destruction during methylaminolevulinate photodynamic therapy of skin tumours located at acral and nonacral sites. Br J Dermatol 2011;164(6):1362-8.

[20] Orenstein A, Kostenich G, Roitman L, Shechtman Y, Kopolovic Y, Ehrenberg B, Malik Z. A comparative study of tissue distribution and photodynamic therapy selectivity of chlorin e6, Photofrin II and ALA-induced protoporphyrin IX in a colon carcinoma model. Br J Cancer 1996;73(8):937-44.

[21] Ibbotson SH, Jong C, Lesar A, Ferguson JS, Padgett M, O'Dwyer M, Barnetson R, Ferguson J. Characteristics of 5-aminolaevulinic acid-induced protoporphyrin IX fluorescence in human skin in vivo. Photodermatol Photoimmunol Photomed 2006;22(2):105-10.

[22] Messmann H, Mlkvy P, Buonaccorsi G, Davies CL, MacRobert AJ, Bown SG. Enhancement of photodynamic therapy with 5-aminolaevulinic acid-induced porphyrin photosensitisation in normal rat colon by threshold and light fractionation studies. Br J Cancer 1995;72(3):589-94.

[23] Curnow A, McIlroy BW, Postle-Hacon MJ, MacRobert AJ, Bown SG. Light dose fractionation to enhance photodynamic therapy using 5-aminolevulinic acid in the normal rat colon. Photochem Photobiol 1999;69(1):71-6.

[24] Robinson DJ, de Bruijn HS, van der Veen N, Stringer MR, Brown SB, Star WM. Fluorescence photobleaching of ALA-induced protoporphyrin IX during photodynamic therapy of normal hairless mouse skin: the effect of light dose and irradiance and the resulting biological effect. Photochem Photobiol 1998;67(1):140-9.

[25] Peng Q, Warloe T, Moan J, Godal A, Apricena F, Giercksky KE, Nesland JM. Antitumor effect of 5-aminolevulinic acid-mediated photodynamic therapy can be enhanced by the use of a low dose of photofrin in human tumor xenografts. Cancer Res 2001;61(15):5824-32.

[26] Juzeniene A, Juzenas P, Bronshtein I, Vorobey A, Moan J. The influence of temperature on photodynamic cell killing in vitro with 5-aminolevulinic acid. J Photochem Photobiol B 2006;84(2):161-6.

[27] Orenstein A, Kostenich G, Kopolovic Y, Babushkina T, Malik Z. Enhancement of ALA-PDT damage by IR-induced hyperthermia on a colon carcinoma model. Photochem Photobiol 1999;69(6):703-7.

[28] Lopez RF, Bentley MV, Delgado-Charro MB, Salomon D, van den Bergh H, Lange N, Guy RH. Enhanced delivery of 5-aminolevulinic acid esters by iontophoresis in vitro. Photochem Photobiol 2003;77(3):304-8. 
[29] Bremner JC, Adams GE, Pearson JK, Sansom JM, Stratford IJ, Bedwell J, Bown SG, MacRobert AJ, Phillips D. Increasing the effect of photodynamic therapy on the RIF-1 murine sarcoma, using the bioreductive drugs RSU1069 and RB6145. Br J Cancer 1992;66(6):1070-6.

[30] Berg K, Anholt H, Bech O, Moan J. The influence of iron chelators on the accumulation of protoporphyrin IX in 5-aminolaevulinic acid-treated cells. $\mathrm{Br} \mathbf{J}$ Cancer 1996;74(5):688-97.

[31] Hanania J, Malik Z. The effect of EDTA and serum on endogenous porphyrin accumulation and photodynamic sensitization of human K562 leukemic cells. Cancer Lett 1992;65(2):127-31.

[32] Liu HF, Xu SZ, Zhang CR. Influence of $\mathrm{CaNa}_{2}$ EDTA on topical 5-aminolaevulinic acid photodynamic therapy. Chin Med J (Engl) 2004;117(6):922-6.

[33] Malik Z, Kostenich G, Roitman L, Ehrenberg B, Orenstein A. Topical application of 5-aminolevulinic acid, DMSO and EDTA: protoporphyrin IX accumulation in skin and tumours of mice. J Photochem Photobiol B 1995;28(3):213-8.

[34] Choudry K, Brooke RC, Farrar W, Rhodes LE. The effect of an iron chelating agent on protoporphyrin IX levels and phototoxicity in topical 5-aminolaevulinic acid photodynamic therapy. Br J Dermatol 2003;149(1):124-30.

[35] Fijan S, Hönigsmann H, Ortel B. Photodynamic therapy of epithelial skin tumours using delta-aminolaevulinic acid and desferrioxamine. $\mathrm{Br} \mathrm{J}$ Dermatol 1995;133(2):282-8.

[36] Uehlinger P, Ballini JP, van den Bergh H, Wagnières G. On the role of iron and one of its chelating agents in the production of protoporphyrin IX generated by 5aminolevulinic acid and its hexyl ester derivative tested on an epidermal equivalent of human skin. Photochem Photobiol 2006;82(4):1069-76.

[37] Ortel B, Tanew A, Hönigsmann H. Lethal photosensitization by endogenous porphyrins of PAM cells--modification by desferrioxamine. J Photochem Photobiol B 1993;17(3):273-8.

[38] Bech O, Phillips D, Moan J, MacRobert AJ. A hydroxypyridinone (CP94) enhances protoporphyrin IX formation in 5-aminolaevulinic acid treated cells. J Photochem Photobiol B 1997;41(1-2):136-44.

[39] Casas A, Batlle AM, Butler AR, Robertson D, Brown EH, MacRobert A, Riley PA. Comparative effect of ALA derivatives on protoporphyrin IX production in human and rat skin organ cultures. Br J Cancer 1999;80(10):1525-32. 
[40] Chang SC, MacRobert AJ, Porter JB, Bown SG. The efficacy of an iron chelator (CP94) in increasing cellular protoporphyrin IX following intravesical 5aminolaevulinic acid administration: an in vivo study. J Photochem Photobiol B 1997;38(2-3):114-22.

[41] Curnow A, McIlroy BW, Postle-Hacon MJ, Porter JB, MacRobert AJ, Bown SG. Enhancement of 5-aminolaevulinic acid-induced photodynamic therapy in normal rat colon using hydroxypyridinone iron-chelating agents. Br J Cancer 1998;78(10):127882.

[42] Curnow A, MacRobert AJ, Bown SG. Comparing and combining light dose fractionation and iron chelation to enhance experimental photodynamic therapy with aminolevulinic acid. Lasers Surg Med 2006;38(4):325-31.

[43] Pye A, Curnow A. Direct comparison of delta-aminolevulinic acid and methylaminolevulinate-derived protoporphyrin IX accumulations potentiated by desferrioxamine or the novel hydroxypyridinone iron chelator CP94 in cultured human cells. Photochem Photobiol 2007;83(3):766-73.

[44] Regula J, MacRobert AJ, Gorchein A, Buonaccorsi GA, Thorpe SM, Spencer GM, Hatfield AR, Bown SG. Photosensitisation and photodynamic therapy of oesophageal, duodenal, and colorectal tumours using 5 aminolaevulinic acid induced protoporphyrin IX - A pilot study. Gut 1995;36(1):67-75.

[45] Smith AG, Clothier B, Francis JE, Gibbs AH, De Matteis F, Hider RC. Protoporphyria induced by the orally active iron chelator 1,2-diethyl-3-hydroxypyridin-4-one in C57BL/10ScSn mice. Blood 1997;89(3):1045-51.

[46] Curnow A. Photodynamic therapy with aminolaevulinic acid (ALA) - Techniques for enhancement. PhD thesis, University College London. 1999, p.89-101.

[47] Blake E, Allen J, Curnow A. The effects of protoporphyrin IX-induced photodynamic therapy with and without iron chelation on human squamous carcinoma cells cultured under normoxic, hypoxic and hyperoxic conditions. Photodiagnosis Photodyn Ther 2013;10(4):575-82.

[48] Campbell SM, Morton CA, Alyahya R, Horton S, Pye A, Curnow A. Clinical investigation of the novel iron-chelating agent, CP94, to enhance topical photodynamic therapy of nodular basal cell carcinoma. $\mathrm{Br} \mathrm{J}$ Dermatol 2008;159(2):387-93.

[49] Pye A, Campbell S, Curnow A. Enhancement of methyl-aminolevulinate photodynamic therapy by iron chelation with CP94: an in vitro investigation and 
clinical dose-escalating safety study for the treatment of nodular basal cell carcinoma. J Cancer Res Clin Oncol 2008;134(8):841-9.

[50] Flora SJ. Structural, chemical and biological aspects of antioxidants for strategies against metal and metalloid exposure. Oxid Med Cell Longev 2009;2(4):191-206.

[51] Ryter SW, Alam J, Choi AM. Heme oxygenase-1/carbon monoxide: from basic science to therapeutic applications. Physiol Rev 2006;86(2):583-650.

[52] Sutton HC, Winterbourn CC. On the participation of higher oxidation states of iron and copper in Fenton reactions. Free Radic Biol Med 1989;6(1):53-60.

[53] Morley N, Clifford T, Salter L, Campbell S, Gould D, Curnow A. The green tea polyphenol (-)-epigallocatechin gallate and green tea can protect human cellular DNA from ultraviolet and visible radiation-induced damage. Photodermatol Photoimmunol Photomed 2005;21(1):15-22.

[54] Singh NP, McCoy MT, Tice RR, Schneider EL. A simple technique for quantitation of low levels of DNA damage in individual cells. Exp Cell Res 1988;175(1):184-91.

[55] Duez P, Dehon G, Kumps A, Dubois J. Statistics of the Comet assay: a key to discriminate between genotoxic effects. Mutagenesis 2003;18(2):159-66.

[56] Boere IA, Robinson DJ, de Bruijn HS, van den Boogert J, Tilanus HW, Sterenborg HJ, de Bruin RW. Monitoring in situ dosimetry and protoporphyrin IX fluorescence photobleaching in the normal rat esophagus during 5-aminolevulinic acid photodynamic therapy. Photochem Photobiol 2003;78(3):271-7.

[57] Haylett AK, Ward TH, Moore JV. DNA damage and repair in Gorlin syndrome and normal fibroblasts after aminolevulinic acid photodynamic therapy: a comet assay study. Photochem Photobiol 2003;78(4):337-41.

[58] Chu ES, Wu RW, Yow CM, Wong TK, Chen JY. The cytotoxic and genotoxic potential of 5-aminolevulinic acid on lymphocytes: a comet assay study. Cancer Chemother Pharmacol 2006;58(3):408-14.

[59] Duez P, Hanocq M, Dubois J. Photodynamic DNA damage mediated by deltaaminolevulinic acid-induced porphyrins. Carcinogenesis 2001;22(5):771-8.

[60] Golab J, Nowis D, Skrzycki M, Czeczot H, Baranczyk-Kuzma A, Wilczynski GM, Makowski M, Mroz P, Kozar K, Kaminski R, Jalili A, Kopec' M, Grzela T, Jakobisiak M. Antitumor effects of photodynamic therapy are potentiated by 2-methoxyestradiol. A superoxide dismutase inhibitor. J Biol Chem 2003;278(1):407-14.

[61] Miccoli L, Beurdeley-Thomas A, De Pinieux G, Sureau F, Oudard S, Dutrillaux B, Poupon MF. Light-induced photoactivation of hypericin affects the energy metabolism 
of human glioma cells by inhibiting hexokinase bound to mitochondria. Cancer Res 1998;58(24):5777-86.

[62] Luo Y, Chang CK, Kessel D. Rapid initiation of apoptosis by photodynamic therapy. Photochem Photobiol 1996;63(4):528-34.

[63] Lin F, Geiger PG, Korytowski W, Girotti AW. Protoporphyrin IX-sensitized photoinactivation of 5-aminolevulinate-treated leukemia cells: effects of exogenous iron. Photochem Photobiol 1999;69(3):375-81.

[64] Fuchs J, Weber S, Kaufmann R. Genotoxic potential of porphyrin type photosensitizers with particular emphasis on 5-aminolevulinic acid: implications for clinical photodynamic therapy. Free Radic Biol Med 2000;28(4):537-48.

[65] Laubach HJ, Chang SK, Lee S, Rizvi I, Zurakowski D, Davis SJ, Taylor CR, Hasan T. In-vivo singlet oxygen dosimetry of clinical 5-aminolevulinic acid photodynamic therapy. J Biomed Opt 2008;13(5):050504.

[66] Sorg O. Oxidative stress: a theoretical model or a biological reality? C R Biol 2004;327(7):649-62.

[67] Zhong JL, Yiakouvaki A, Holley P, Tyrrell RM, Pourzand C. Susceptibility of skin cells to UVA-induced necrotic cell death reflects the intracellular level of labile iron. $\mathbf{J}$ Invest Dermatol 2004;123(4):771-80.

[68] Valko M, Rhodes CJ, Moncol J, Izakovic M, Mazur M. Free radicals, metals and antioxidants in oxidative stress-induced cancer. Chem Biol Interact 2006;160(1):1-40. 


\section{Figure legends}
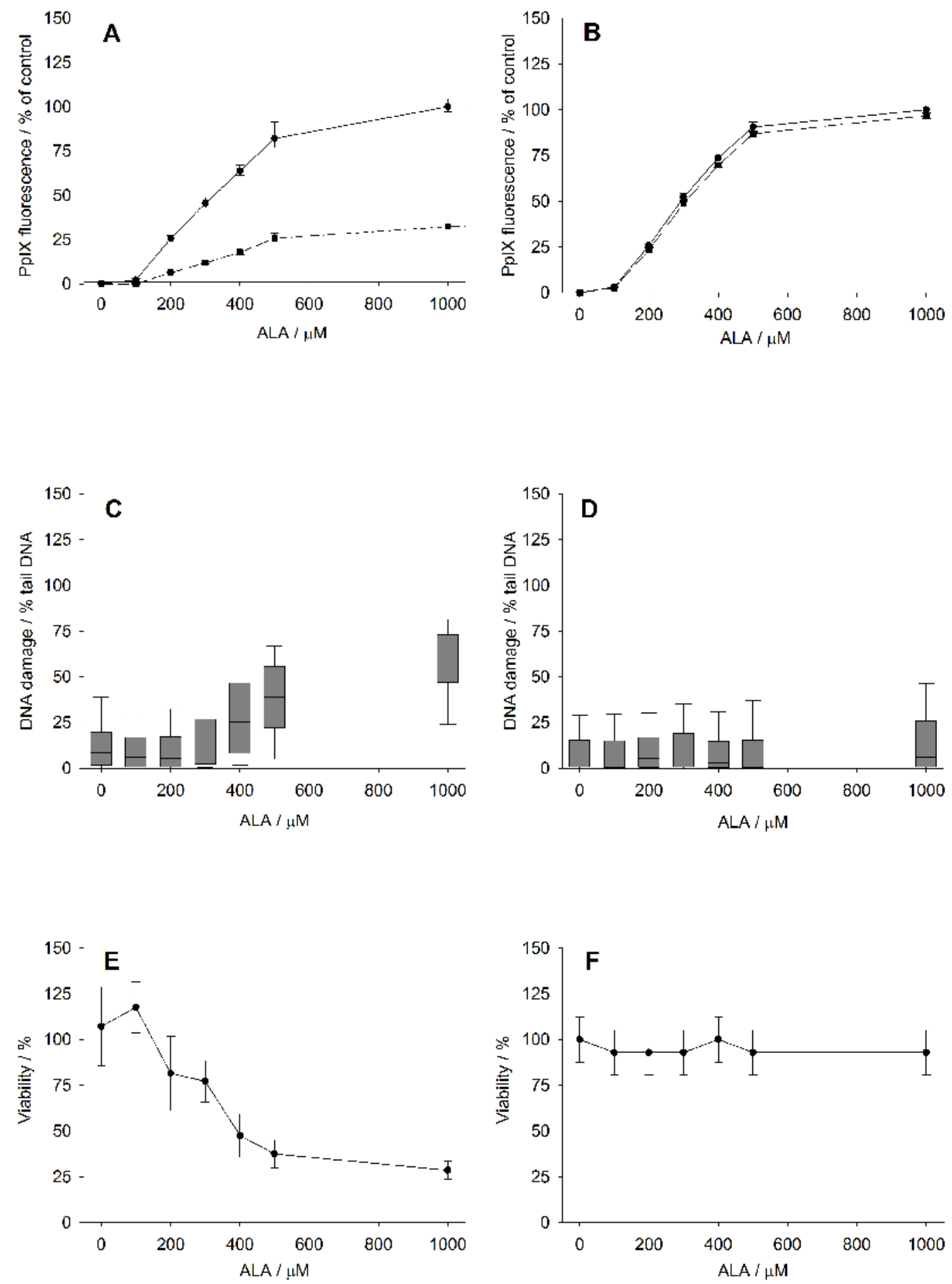

Figure 1 Results observed with MRC-5 cells incubated with various concentrations (0 to $1000 \mu \mathrm{M})$ of ALA for $6 \mathrm{~h}$. Mean $( \pm$ SD) PpIX fluorescence before (solid line) and after irradiation (dashed line) with (A) or without (B) $15 \mathrm{~J} / \mathrm{cm}^{2} 635 \mathrm{~nm}$ light delivery. Box-andwhisker plots of median DNA damage with $(C)$ or without (D) irradiation. Mean $( \pm$ SD) trypan blue cell viability with $(\mathrm{E})$ or without $(\mathrm{F})$ irradiation. 

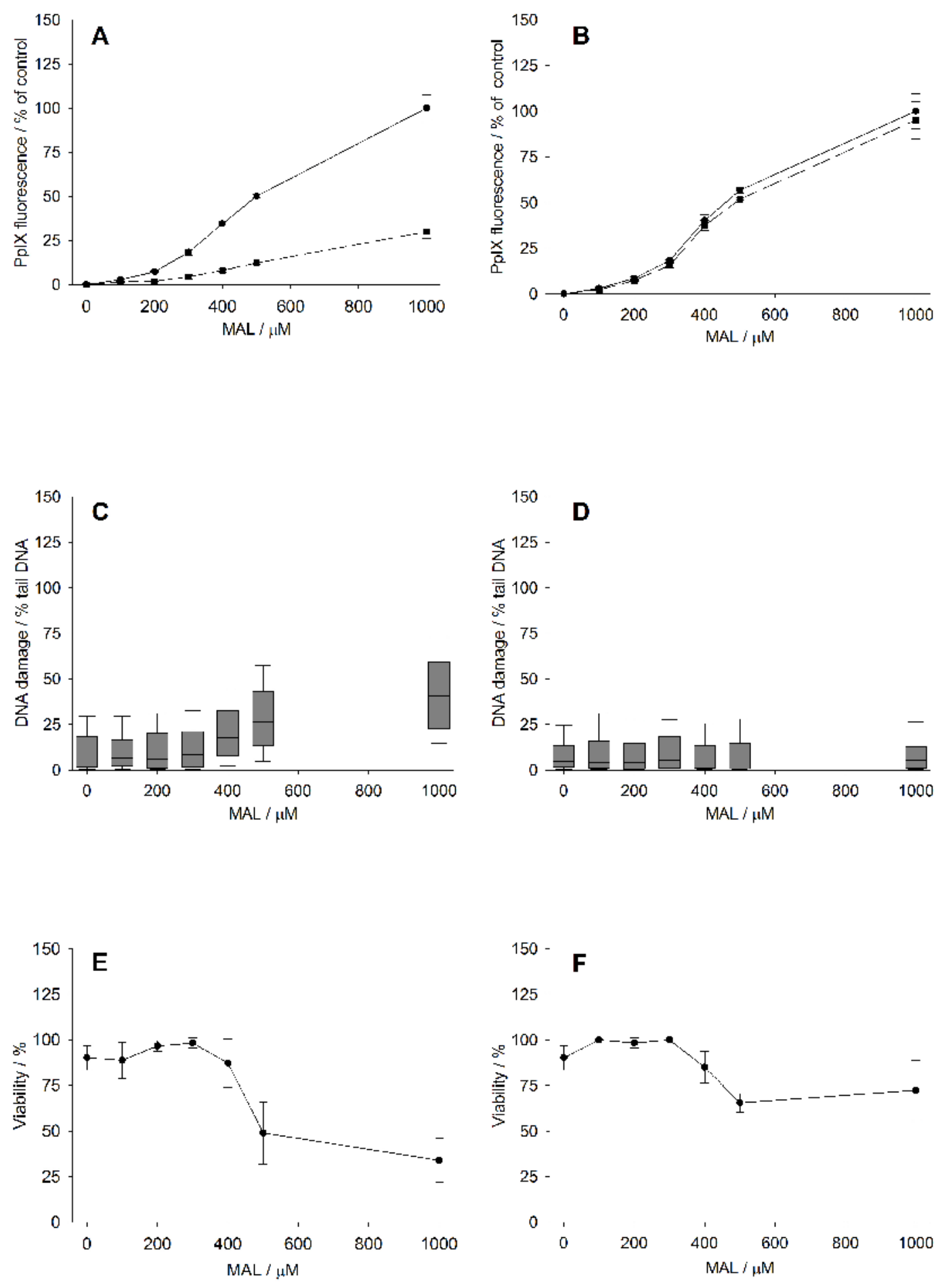

Figure 2 Results observed with MRC-5 cells incubated with various concentrations (0 to $1000 \mu \mathrm{M})$ of MAL for $6 \mathrm{~h}$. Mean $( \pm \mathrm{SD})$ PpIX fluorescence before (solid line) and after irradiation (dashed line) with (A) or without (B) $15 \mathrm{~J} / \mathrm{cm}^{2} 635 \mathrm{~nm}$ light delivery. Box-andwhisker plots of median DNA damage with $(C)$ or without (D) irradiation. Mean $( \pm$ SD) trypan blue cell viability with $(\mathrm{E})$ or without $(\mathrm{F})$ irradiation. 

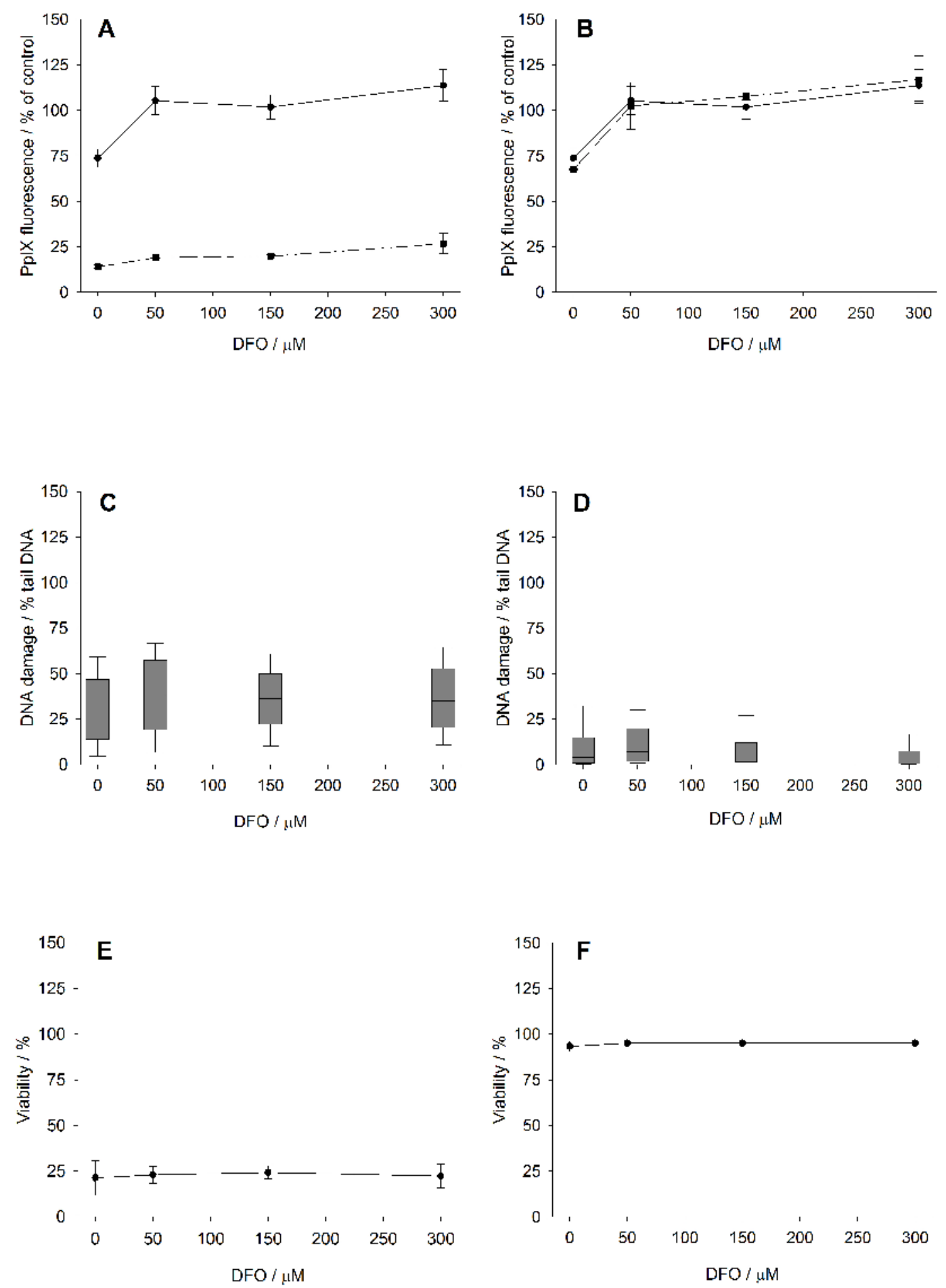

Figure 3 Results observed with MRC-5 cells incubated with $500 \mu \mathrm{M}$ ALA plus increasing concentrations of DFO $(0$ to $300 \mu \mathrm{M})$ for $6 \mathrm{~h}$. Mean $( \pm$ SD) PpIX fluorescence before (solid line) and after irradiation (dashed line) with (A) or without (B) $15 \mathrm{~J} / \mathrm{cm}^{2} 635 \mathrm{~nm}$ light delivery. Box-and-whisker plots of median DNA damage with (C) or without (D) irradiation. Mean $( \pm$ SD) trypan blue cell viability with $(\mathrm{E})$ or without $(\mathrm{F})$ irradiation. 

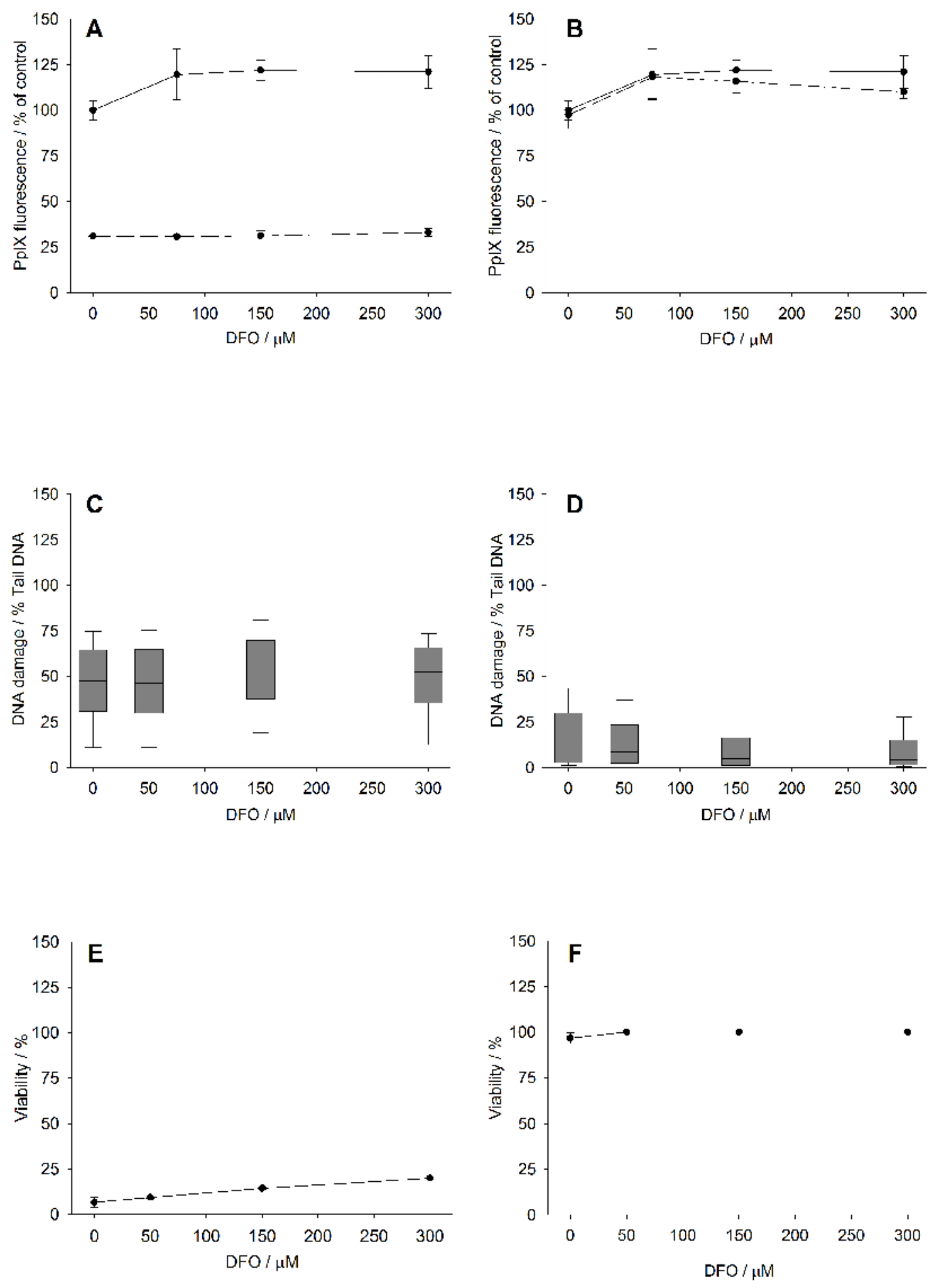

Figure 4 Results observed with MRC-5 cells incubated with $1000 \mu \mathrm{M}$ MAL plus increasing concentrations of DFO $(0$ to $300 \mu \mathrm{M})$ for $6 \mathrm{~h}$. Mean $( \pm$ SD) PpIX fluorescence before (solid line) and after irradiation (dashed line) with (A) or without (B) $15 \mathrm{~J} / \mathrm{cm}^{2} 635 \mathrm{~nm}$ light delivery. Box-and-whisker plots of median DNA damage with (C) or without (D) irradiation. Mean $( \pm \mathrm{SD})$ trypan blue cell viability with $(\mathrm{E})$ or without $(\mathrm{F})$ irradiation. 

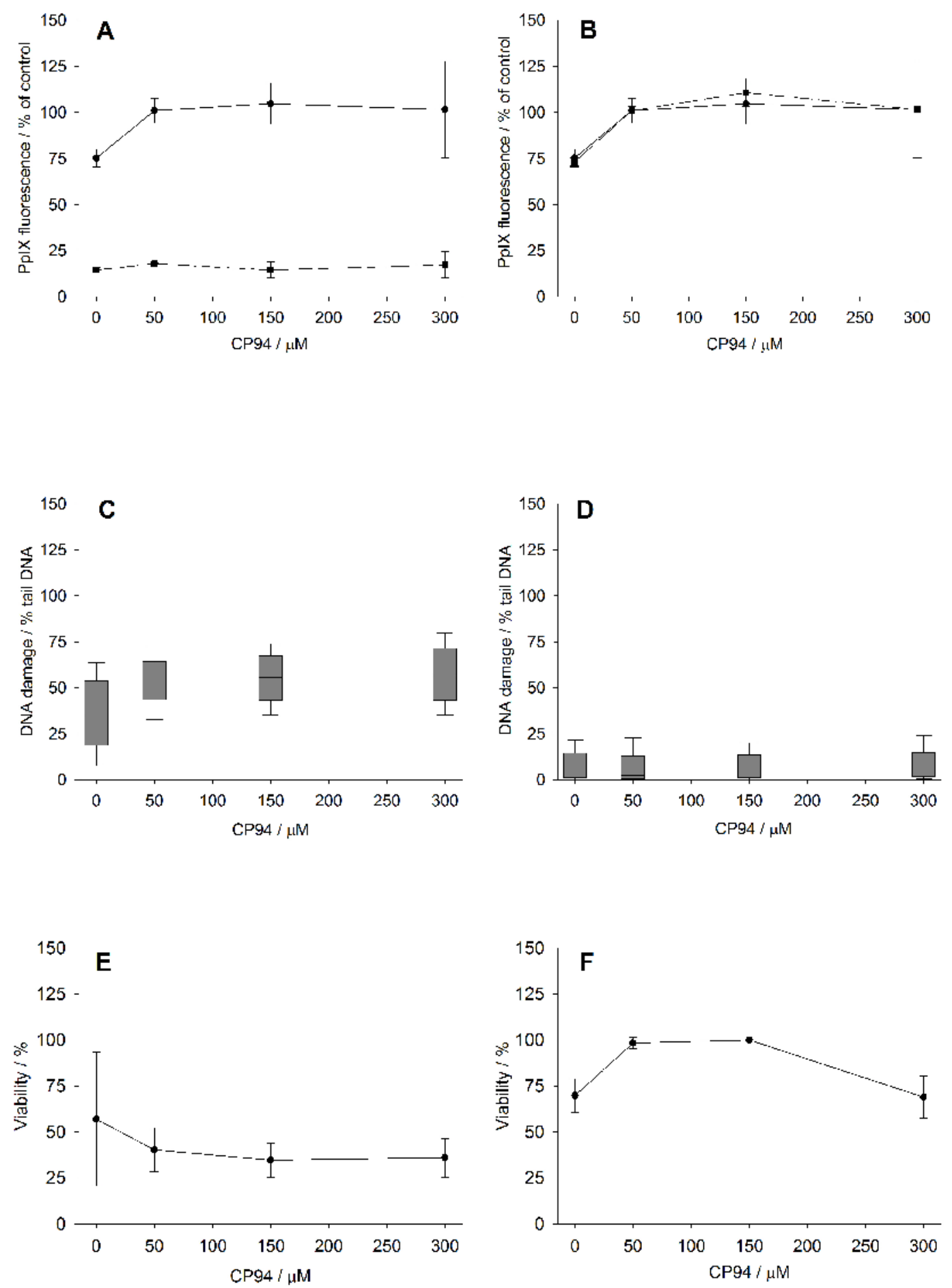

Figure 5 Results observed with MRC-5 cells incubated with $500 \mu \mathrm{M}$ ALA plus increasing concentrations of CP94 $(0$ to $300 \mu \mathrm{M})$ for $6 \mathrm{~h}$. Mean $( \pm$ SD) PpIX fluorescence before (solid line) and after irradiation (dashed line) with (A) or without (B) $15 \mathrm{~J} / \mathrm{cm}^{2} 635 \mathrm{~nm}$ light delivery. Box-and-whisker plots of median DNA damage with (C) or without (D) irradiation. Mean $( \pm$ SD) trypan blue cell viability with $(E)$ or without $(F)$ irradiation. 

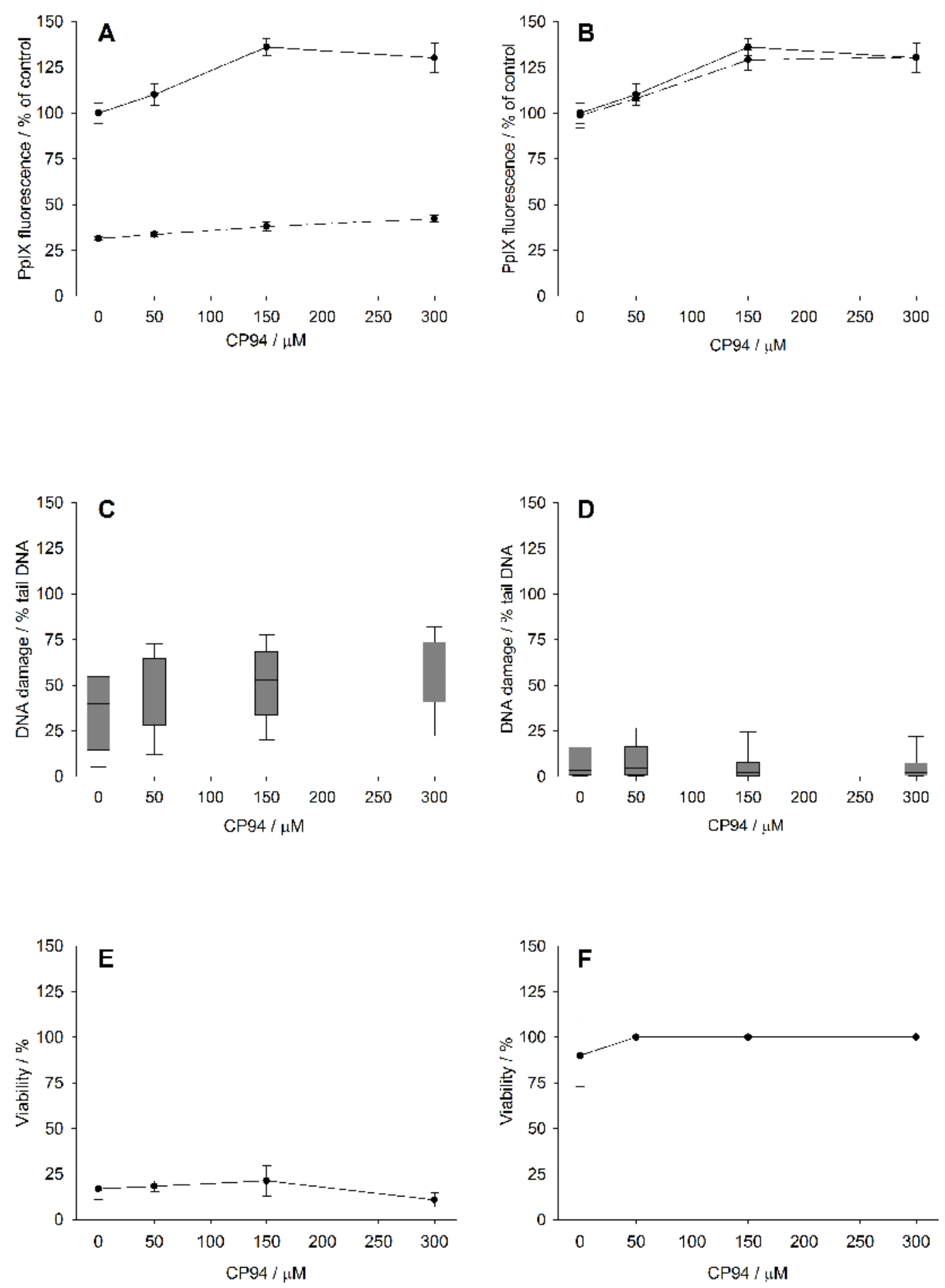

Figure 6 Results observed with MRC-5 cells incubated with $1000 \mu \mathrm{M}$ MAL plus increasing concentrations of CP94 $(0$ to $300 \mu \mathrm{M})$ for $6 \mathrm{~h}$. Mean $( \pm$ SD) PpIX fluorescence before (solid line) and after irradiation (dashed line) with (A) or without (B) $15 \mathrm{~J} / \mathrm{cm}^{2} 635 \mathrm{~nm}$ light delivery. Box-and-whisker plots of median DNA damage with (C) or without (D) irradiation. Mean $( \pm \mathrm{SD})$ trypan blue cell viability with $(\mathrm{E})$ or without $(\mathrm{F})$ irradiation. 

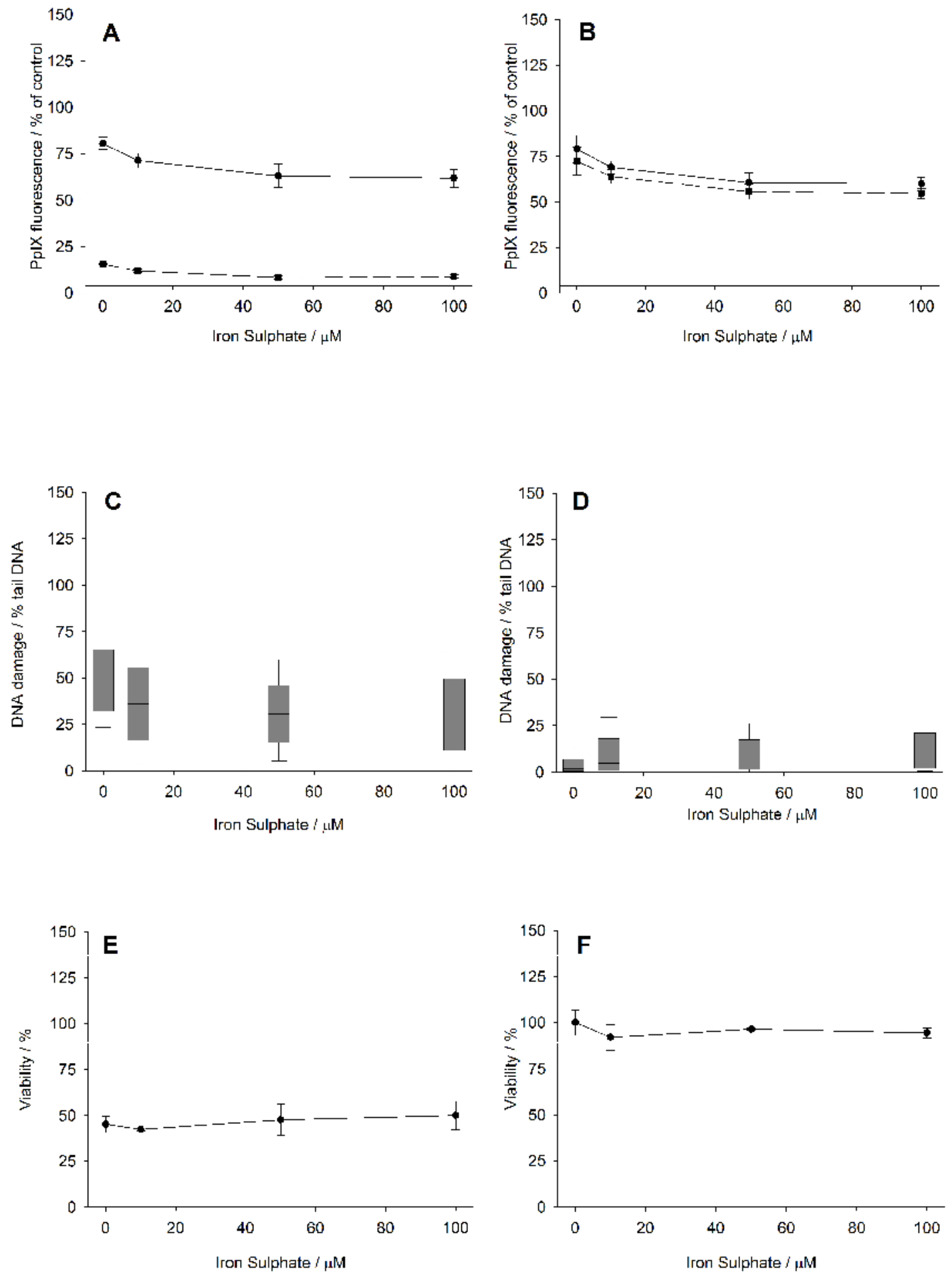

Figure 7 Results observed with MRC-5 cells incubated with $500 \mu \mathrm{M}$ ALA plus increasing concentrations of iron sulphate $(0$ to $100 \mathrm{mM})$ for $6 \mathrm{~h}$. Mean $( \pm \mathrm{SD})$ PpIX fluorescence before (solid line) and after irradiation (dashed line) with (A) or without (B) 15 $\mathrm{J} / \mathrm{cm}^{2} 635 \mathrm{~nm}$ light delivery. Box-and-whisker plots of median DNA damage with (C) or without (D) irradiation. Mean ( \pm SD) trypan blue cell viability with (E) or without (F) irradiation. 

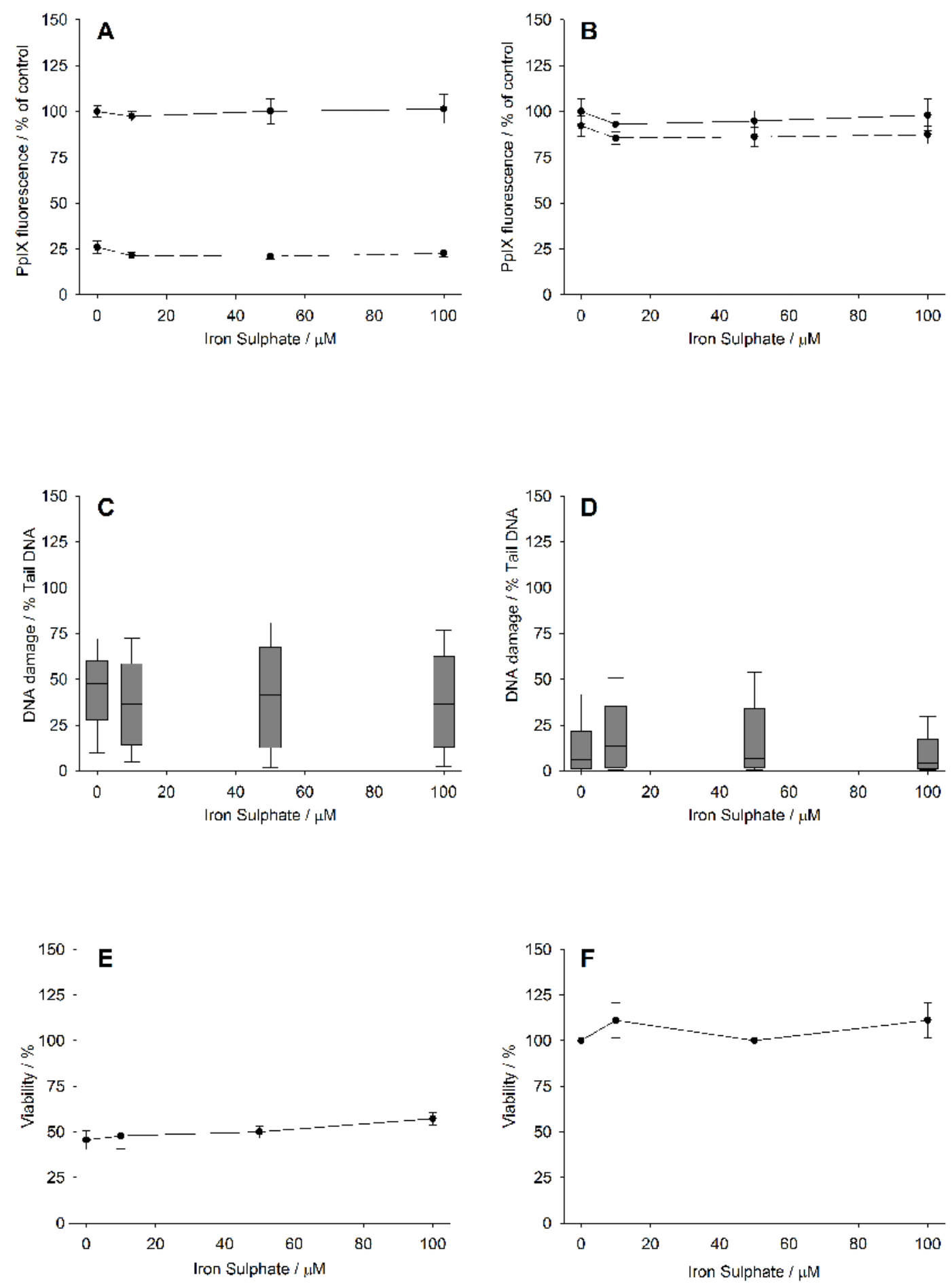

Figure 8 Results observed with MRC-5 cells incubated with $1000 \mu \mathrm{M}$ MAL plus increasing concentrations of iron sulphate $(0$ to $100 \mu \mathrm{M})$ for $6 \mathrm{~h}$. Mean $( \pm \mathrm{SD})$ PpIX fluorescence before (solid line) and after irradiation (dashed line) with (A) or without (B) 15 $\mathrm{J} / \mathrm{cm}^{2} 635 \mathrm{~nm}$ light delivery. Box-and-whisker plots of median DNA damage with (C) or without (D) irradiation. Mean ( \pm SD) trypan blue cell viability with (E) or without (F) irradiation. 